\title{
Exploration of the Pedagogy of Civic Education in Social Studies Lessons to Support Learner Transformation in Selected Schools in Masaiti district: A Hermeneutic Phenomenological Approach
}

\author{
S. M. Mufalo, G. Muleya, F. Simui
}

\section{ABSTRACT}

The paper examines how the teaching of Civic Education in Social Studies lessons is conducted to support learner transformation. The study was qualitative in nature, driven by a hermeneutic phenomenological design. Twelve (12) participants from selected schools and the Ministry of Education District Education Board Secretary's office were sampled through homogenous purposive sampling. Data generation for the study was through semi-structured interviews, semi-structured questionnaires, observation schedules and document analysis. What emerged from the study was that teacher-centred mode of delivery was mostly used by teachers of Civic Education during classroom delivery as compared to use of learner-centred activities. Further, it was discovered that there were very few teachers who were trained in Civic Education. Hence, most of the teachers who taught Civic Education component in Social Studies lessons were trained in other subjects such as History, Geography, Business Studies, Psychology, Religious Education and Special Education among others. Therefore, these teachers taught the component on secondment basis due to the shortage of qualified teachers of Civic Education in schools. In this regard, the study revealed that these teachers had limitations in pedagogical knowledge. Therefore, the study recommended among others that teachers of Civic Education should employ $21^{\text {st }}$ century teaching approaches (learner-centred activities) during their delivery. In addition, the Ministry of Education should employ more qualified teachers of Civic Education in schools. Further, it was recommended that the Ministry of Education and the Curriculum Development Centre through the District Education Board Secretary officials and school authorities should enhance Continuous Professional Development programmes (CPDs) in schools.

Keywords: Civic Education, Learner Transformation, Pedagogical Knowledge, Social Studies

\section{INTRODUCTION}

Over the years, Zambia has experienced a high demand for secondary education and an increase in school enrolments in the country which has led to many primary schools being upgraded into secondary schools some of which are known as combined schools since they run from early childhood (pre-school) up to grade twelve [senior secondary school] (Mufalo et al., 2021). In line with this development, the Ministry of Education in 2013 revised its curricula from pre-school up to tertiary level (MoE, 2013). This was in the quest to produce a holistically developed cadre who would be ready to navigate through the challenges and dynamism of the $21^{\text {st }}$ century in the contemporary society. Arising from this curriculum review,
Published Online: February 18, 2022

ISSN: $2736-4534$

DOI :10.24018/ejedu.2022.3.1.272

\section{S. M. Mufalo*}

Mishikishi Secondary School,

Masaiti, Zambia.

(e-mail: setwinmutau@gmail.com) G. Muleya

Institute of Distance Education,

University of Zambia, Lusaka, Zambia.

(e-mail: muleya71@yahoo.com)

F. Simui

Institute of Distance Education,

University of Zambia, Lusaka, Zambia.

(e-mail: francis.simui@ unza.zm)

*Corresponding Author
Civic Education at junior secondary school (grade 8 \& 9) was integrated into a subject called Social Studies for the first time which is an amalgamation of Civic Education, History and Geography. However, at senior secondary school level, Civic Education is currently taught as a standalone subject so is Geography and History. Suffice to state that Civic Education was re-introduced at senior secondary school (grades 10 to 12) in 2004 (Magasu et al., 2020b).

According to the Ministry of Education, Science, Vocational Training and Early Education [MESVTEE] (2013; x), the aim of Social Studies is to develop "an understanding of the economic, political, civic, cultural, geographical and historical factors which influence social development." At senior secondary school, Civic Education 
aims at "creating an understanding of the political process and appreciation of good governance; promoting positive attitudes, responsibilities, duties, obligations, freedoms and rights of a citizen in the learner; creating awareness on the need for respect, promotion of democracy, human rights and freedoms; and developing an understanding of global issues" (MESVTEE, 2013; 3). Therefore, in order to achieve these outlined general outcomes, the government pledged to provide quality education for all and promote school effectiveness through improved school governance and management, community involvement and curriculum development (MoE, 2019; MoNDP, 2017; MoE, 2013; MoE, 1996).

Notably, Civic Education is not only limited to the formal structures of the school system but also goes beyond (Muleya, 2018a). However, the current study was confined only to how Civic Education is taught at junior secondary school. In other words, the study concentrated on the pedagogical approaches or teachers' pedagogical knowledge with regard to the delivery of Civic Education. Mufalo (2021) describe pedagogical knowledge as the methodological knowledge on how to present the subject matter in the classroom using different methods, strategies and techniques. Further, Mufalo (2021) posits that if a teacher has limited pedagogical knowledge, it may affect subject delivery, learner acquisition of Civic Education profile dimensions hence, affecting learner transformation possibilities.

\section{REVIEW OF RELATED LITERATURE}

\section{A. Pedagogical Approaches in the Teaching of Civic} Education

Kousar and Brett (2020) carried out a study on gender imbalances/balances in the Pakistani curriculum. The study revealed that Citizenship Education was integrated into Social Studies (History, Geography \& Civics) and Pakistan Studies from years 1-10, while at senior secondary school and university levels, Civics was being taught as an optional subject. Further, the study found that Citizenship Education in Pakistan was being taught using didactic transmission methods due to overloaded classrooms. A didactic method is a method of teaching where the teacher is perceived to be the container of knowledge and learners are simply recipients of the subject matter knowledge. In some instances, learners may not even question the teacher on the subject matter since it is teacher-centred mode of delivery which makes them to be passive learners and listeners. The study was conducted mainly to analyse the Pakistani curriculum in terms of gender imbalances/balances not on pedagogical approaches in the teaching of Civic Education.

Further, Mohit (2018) conducted a study at Colonel Ganj Intermediate School of Allahabad in India aiming to observe teaching of Civic Education and how students interacted in a civic classroom. The study revealed that only one teacher was observed using debate during teaching while others used traditional methods of teaching which encouraged rote memory. This narrative was supported by a question from one pupil who asked the teacher, "Are we still going to continue with rote learning? See in the southern and other states of India the education system is fast modernizing!", (Mohit, 2018: 28). The study further revealed that teachercentred mode of delivery was also observed from a different teacher who felt bad and alleged that pupils disturbed her by asking questions during teaching. This complaint meant that the teacher was using teacher-centred method during her lesson delivery a scenario which led to one pupil sleeping in class as noticed by both the teacher and the researcher. Additionally, the study pointed out that the educational system at the Colonel Ganj Intermediate School did not have a fundamentally rigid rule towards its approach to pedagogy. The status-quo might have contributed to the observed variations in the application of teaching methods. It should be stressed that during lesson delivery, teachers should use a variety of teaching methods, strategies and techniques which stimulate creativity and critical thinking among learners.

Another study was carried out in three (3) Israeli secondary schools (Nir, Dror \& Zohar secondary schools) which focused on the ways in which teachers' assumptions and goals regarding citizenship influence their teaching of civics (Cohen, 2013). The study established that, out of the three (3) sampled teachers, one teacher used lecture method while the other 2 teachers used learner-centred method during Civic Education lessons. Further, the study observed that there were disparities in the teaching of the concept 'good citizenship' among the three Israeli secondary schools. One could infer from the revelation that the variations in citizenship conceptions might have been attributed to insufficient content knowledge among teachers. Therefore, the use of teacher-centred method during Civic Education lessons should be discouraged because it encourages rote learning. Rote learning encourages learners to memories the content taught which they may recite later on like parrots without understanding it. This inhibits the development of creative skills and critical thinking skills among learners. Consequently, it is imperative for teachers to have sufficient Civic Education content knowledge because, it helps pupils to learn properly than when it is poor (Mufalo et al., 2021) citing Kind and Chan (2019).

The recent study that was conducted in Europe by Cekse (2021) on 'Improving Civic and Citizenship Education in Latvia' revealed that teachers with degrees in Social Sciences taught the subject at lower-school level (grade 1 to 9). Cekse also, stated that Civic and Citizenship Education (Civic Education) in schools was taught using three approaches namely; direct teaching and learning in class, out-of-class activities like engagement in school council and civic projects and through common civic school culture. However, the article particularly focused on a large school education reform carried out in Latvia since 1991 not on the pedagogical approaches in the teaching of Civic Education.

Similarly, the study done by USAID (2018) in Poland established that the introduction of Civic Education contributed to the rapid transition of the country from a communist society that relied on martial law to a democratic society. Further, the study revealed that students were exposed to open classroom environments. This meant that the subject was being taught using learner-centred activities which enabled students and teachers to have open class discussions. On the contrary, the study that was conducted in Ukraine found that didactic teaching styles were prevalent 
during the teaching and learning of Civic Education. The study recommended for a departure from such methods of instruction to student-centred teaching methodology (USAID, 2018). Furthermore, USAID indicated that Romania had the biggest issue of teaching methodologies used in schools as they largely used dictatorial teaching styles which prevented learners from debating ideas in the classroom.

In Italy, the study by Bombardelli and Codato (2017) revealed that the teaching methods used during the delivery of Civic Education were dependent upon schools and teachers because they had the responsibility to decide on the choice of teaching methods. It was also found that group work was not common because most teachers held the view that working in groups was not effective. The study further discovered that only a few teachers used innovative teaching methods. This was despite Circular letter 86/2010 which encouraged methods fostering the active role and participation of students especially in schools in which strong traditional teaching methods were the norm (Bombardelli \& Codato, 2017). Nonetheless, their study was a document analysis.

Zabun and Bektas (2019) also did research in Turkey and France aimed at comparing Turkey's Human Rights, Citizenship and Democracy Lesson Education Programme with France's Moral and Civic Education programme. The results were that Civic Education in Turkish secondary schools was taught using question and answer, brainstorming, discussion, visual reading, inference, observation, comparison and reminder techniques while France organized revealing values methods and role-play technique during subject delivery. These research findings indicate that learners were in the centre stage in terms of learning because varieties of learner-engagement techniques were employed during lessons. Again this study was a comparative study on human rights, citizenship and democracy not on pedagogical approaches in Civic Education.

In North America Canada to be precise, Bickmore (2014) did a study on 'Democratic engagement with differences, conflicts and equity issues'. The study revealed that despite the curriculum policy emphasizing on student-centred pedagogy, Citizenship Education was taught using teachercentred mode of delivery and student memorization of content information without much attention to thinking or skills development. Furthermore, Bickmore added that Civic Education was embedding in day-to-day school related activities and relationships namely, patterns of discipline and conflict management, community service activities, and student voice and leadership roles. This embedment affected Canadian students especially those from less privileged backgrounds because they had few opportunities to practice democratically relevant citizenship learning in school (Bickmore, 2014).

Further, Zuniga et al. (2020) conducted a study among teachers in Chile who were rated outstanding in the Chilean Teacher Evaluation System. It was discovered that those teachers applied multiple teaching/learning activities such as individualistic, pair, small group and whole class activities during Citizenship Education lessons. The exhibited outstanding performance was because of the conducive open classroom environments that were created where learners and teachers could openly discuss issues during class activities. Therefore, such teaching/learning activities emphasized the development of higher skills over memorization (Zuniga et al., 2020). It is important to state that the use of $21^{\text {st }}$ century teaching approaches is beneficial to both the teacher and learners at large. This is because such pedagogical approaches enhance effective delivery and learner acquisition of profile dimensions, which in turn fortify learner transformation possibilities. Nevertheless, the study concentrated mainly on learner performance not on pedagogical approaches in the teaching of Civic Education.

The study that was conducted in Nigeria by KayodeOlawoyin (2017) revealed that Civic Education was compulsory and taught in all primary and secondary schools. However, the study further discovered that the subject was confronted with the problem of rote learning methods of teaching. Reinforcing the above study finding, Falade and Adeyemi (2015 in Kayode-Olawoyin, 2017) pointed out that the teaching method of rote learning with memorization in Civic Education was the most prominent method of delivery. This implied that teachers taught the subject with teaching strategies which merely encouraged memorizing the subject matter which impeded learners' critical thinking skills. In other words, rote learning can be termed as a ' 6 tone bull elephant' occupying Civic Education lessons in many countries across the globe more especially in Africa which is an inhibitor in creating learner transformation. Therefore, it was recommended that workshops and seminars should be organized for Civic Education teachers in order to equip them with training and teaching expertise necessary in the subject delivery.

Similarly, Alemnge and Andongaba (2021) carried out a study in Cameroon which investigated 'the impact of methods and materials on the teaching of Citizenship Education in Secondary Schools in the Buea Municipality'. The findings revealed that Citizenship Education teachers were mostly using teacher-centred method in teaching the subject which contradicted learner-centred method prescribed in the syllabus. The study also found that teachers did not have Citizenship Education syllabi and their sources of information for the teaching process were textbooks. Further, it was observed that some teachers were not using instructional materials during teaching and the majority heavily relied on the use of textbooks in the teaching of Citizenship Education. Consequently, it is important to state that when teachers prepare their work without following the syllabus, it affects subject delivery, learner transformation and performance. This is because they may not be aware of the course outline or specific outcomes and objectives stated in the syllabus which the subject intends to achieve at the end of the topic or course.

Corresponding with the above revelations, the study by Bayeh (2016) in Ethiopia also found that Civics and Ethical Education (Civic Education) was taught using plasma as a method of delivery to learners. Plasma method of delivery is where teaching is done through the television broadcast and learners follow the teacher's presentation or broadcast. Tesfaye et al. (2013) in Bayeh (2016) argued that this mode of delivery affected learners in terms of acquisition of relevant knowledge and skills from the subject. This is so in 
the sense that the subject was being delivered on a remote control type of learning where learners sit and follow the teacher's presentation on television without face-to-face interaction. The demerit of this type of teaching is that learners have no time to ask the teacher questions on the topic at hand and that which they feel was not adequately taught. In addition, when there is an interruption in terms of power supply, learners miss out completely because the lesson may not be rewound. Therefore, participatory and interactive methods of teaching such as role playing, problem-solving activities are best received and appear to deliver better and long-term results (Browne, 2013; EU, 2011) as cited by Bayeh (2016). Consequently, eclectic approaches should be employed by all Civic Education teachers during lesson delivery in order to attain effective teaching which in turn enhances learner transformation at large. Nevertheless, his study was not on pedagogical approaches in the teaching of Civic Education but it was meant to examine the role of Civics and Ethical Education (Civic Education) in building the good behaviour of citizens and making them active participants in the development of democratic governance.

In Botswana, Citizenship Education at junior secondary school was found to be taught using inquiry methods and group work (Adeyem et al., 2003). The researchers further explained that the strategies of inquiry and use of group work during the teaching and learning process enhanced the achievement of producing good citizens. On the contrary, the study done by Boikhutso et al. (2013) in Botswana revealed that Social Studies (an integration of Citizenship Education) was found to be delivered through the use of old method of telling their students instead of engaging them to harness information themselves. This meant that teachers were delivering the subject using teacher-centred mode of delivery. It can be deduced that as time elapses, teachers tend to relax and drift away from recommended learnercentred teaching techniques due to a number of factors namely; large class sizes, demotivation and lack of teaching/learning material among others. However, the study was meant to investigate the perceptions on the role of Botswana's Social Studies teachers at secondary school level in fostering citizenship competencies and skills.

Similarly, the study done by Magasu et al. (2020a) in Lusaka, Zambia discovered that lecture method was the common method of teaching which teachers used during Civic Education lessons. Their study further revealed that only a few teachers used debate, group discussions and brainstorming. This revelation by the researchers was against the Zambia Education Curriculum Framework of 2013, which encouraged teachers of Civic Education to use learner-centred approaches in the teaching and learning process because they encourage learners to reflect, think and do rather than reproduce from rote learning (MoE, 2013). Besides, the teaching and learning methods that encourage learners to reflect upon their situation and circumstances in their lives stimulates critical thinking which may enhance learner transformation (Muleya, 2019). On the contrary, the study done by Mainde et al. (2021) in Lusaka district, Zambia revealed that teachers of Civic Education used both lecture and learner-centred methods. Their study recommended that schools should strengthen Continuous
Professional Development (CPD) activities such as Lesson Study Cycles, Cluster Meetings among others so that they promote Civic Education pedagogies for effective teaching and learning. This is because sufficient acquisition of pedagogical knowledge by the teacher is key to student achievement (Mufalo et al., 202; Muntengwa et al., 2020). However, teachers with insufficient teaching skills may lead to the arch of excellence in schools to collapse (Akinyemi Olufunminiyi \& Abiodun Adekunle, 2019).

\section{Methodology}

\section{A. Research Design}

The study was qualitative in nature. A qualitative research is a phenomenological inquiry that uses a naturalistic approach that seeks to understand phenomena in specific settings (Shava \& Nkengbeza, 2020). Hermeneutic phenomenological design was employed. This approach allows the researcher to make inferences about informants' experiences beyond that which is conveyed (Simui, 2018). In other words, hermeneutic phenomenological approach permits the researcher to perceive beyond the conveyed lifeworld of participants.

\section{B. Study Site, Population and Sample Size}

The study was conducted in Masaiti district one of the rural districts on the Copperbelt province of Zambia. The target population comprised Ministry of Education district officials, school administrators, Heads of Department, Heads of Section-Civic Education and teachers of Civic Education. The sample size for the participants was 12 comprising 2 female and 10 males determined a posteriori. The sample size was determined a posteriori because determining the sample size a priori would have been a challenge since the study employed interpretive phenomenological approach where themes could not be determined or identified in advance.

\section{Sampling Procedure}

All the 12 participants were selected through homogenous purposive sampling. This was because participants had similar characteristics and were easily accessible.

\section{Research Instruments}

Data from participants was gathered using semi structured interview guides, semi structured questionnaires and observation guides.

\section{E. Data Gathering Procedure}

Permission was sought from the Provincial Education Officer (PEO) prior to commencement of data generation. Semi-structure interviews, semi-structure questionnaires and observation schedules were used to gather data from participants. Also, data from interviews was recorded using a voice recorder and a diary.

\section{F. Data Analysis}

Gathered data was thematically analysed. This was done by identifying similar ideas that were later grouped together (coding) in order to come up with themes (Mufalo \& Kabeta, 2019). All participants were given pseudonyms such 
as Nda, Ndu, Ngo, Peba... for anonymity and confidentiality purposes. Suffice to state that the four (4) existential dimensions espoused by van Manen (1990/1997 in Guimond-Plourde, 2009) namely: corporeality, spatiality, temporality and relationality guided the analysis of the lifeworlds of participants.

\section{G. Ethical Considerations}

Before commencement of the study, the research proposal was approved by Humanities and Social Science Research Ethics Committee (HSSREC) of the University of Zambia and the study approval number was HSSREC-2021-OCT010. Also, permission was sought from the Provincial Education Officer. In addition, pseudonyms were given to all the participants and the researcher assured them that the data gathered was strictly treated with the maximum confidentiality and anonymity it deserved and that it was to be used only for academic purposes. All the materials used during the process of data production were kept safe.

\section{PRESENTATION}

When participants were asked how the teaching of Civic Education in Social Studies lessons was conducted in schools to support learner transformation possibilities, most participants held the view that teachers taught the subject in schools using traditional mode of delivery. This meant that these teachers had limited pedagogical knowledge. This was because most of the teachers who taught the component were not trained in Civic Education but were just seconded to teach the subject hence, the use of not recommended teaching method. Tou observed the following as indicated in the verbatim:

'... most teachers teach on secondment basis'

(Tou.p11,04.11.2021).

Therefore, the teachers on secondment basis were trained in subjects such as History, Geography, Religious Education, Business Studies, Special Education, Information and Communication Technology (ICT), Psychology and Civics among others where the majority had degrees and others had diplomas in their specializations. Others were primary school teachers and only a few teachers were trained in Civic Education. The secondment of these teachers to teach Civic Education component was due to shortage of qualified Civic Education teachers in schools. Participants further stated that the seconded teachers had limitations regarding the three knowledge domains namely; content knowledge, curriculum knowledge and pedagogical knowledge.

'...Not qualified teachers teaching it [Civic Education]. Because of this, they may have challenges in content knowledge and pedagogical skills' (Nda.P3, 06.08.2021).

Similar views were expressed by $\mathrm{Ngo}$ who had this to say:

'In the few schools which I have visited in this area I would say the teachers that are teaching are very few that have done specifically Civic Education...Hence, some are still seconded teachers those who were trained under Civics. Coming to the content I would still say few have but the majority they do not have that content per say as to the new subject Civic Education the way it is...those that have not gone further to do specifically Civic Education as it is now. Teaching methods they are trying but not up to date' (Ngo.p2, 04.08.2021).

On the contrary, participants like Ndu, Peba and Lii said that teachers who were teaching Civic Education had knowledge of the content, knowledge of the curriculum and used a variety of teaching methods.

'On this one [content knowledge], for me they have the knowledge of content depending on the topic. There are some topics where they have difficulties in delivering the content. So far from the people I have known here [the school] they have the knowledge of teaching. This one I will talk about myself now. Depending of the lesson, I use different methods' (Ndu.p4, 31.08.2021).

'The content is okay, most teachers have the knowledge but more needs to be done to equip teachers with the current trends...' (Peba.P12, 15.09.2021).

Lii who is a Head of section Civic Education also supported the above statements.

'At this school which is [...] all the teachers handling this subject are qualified and they have the content knowledge and we do follow the curriculum...Actually we do use various teaching methods. For example, we do have document study, group discussion, teacher exposition and we do advise ourselves to offer home works to the learners' (Lii.P5, 01.09.2021).

Despite few participants saying that, the subject was taught using different teaching methods, most of the participants said that teacher-centred method was widely used by teachers. This was due to limited pedagogical skills among teachers, limited delivery time and large class sizes among others. During some lesson observations, the researcher confirmed the views of the majority where it was observed that Civic Education in Social Studies lessons was taught using traditional mode of delivery.

\section{DisCUSSION OF FINDINGS}

The revelation from the study was that traditional mode of delivery was the most prominent teaching method, which was being used by teachers in schools [spatiality]. This was due to among others large class sizes, limited pedagogical skills and limited time ( 80 minutes per week) [temporality] allocated to the Civic Education component. This establishment relates to the study that was conducted in Asia where it was discovered that Citizenship Education in Pakistan was being taught using didactic transmission methods due to overloaded classrooms (Kousar \& Brett, 2020). Similarly, Bickmore (2014) reported that Civic Education in Canada was taught using teacher-centred mode of delivery where there was student memorization of content 
information without much attention to thinking or skills development. This situation was also discovered in Romania by USAID (2018) where it was established that the biggest issue in schools was in terms of teaching methodologies used. This was because they largely used dictatorial teaching styles, which prevented learners from debating ideas in the classroom. This meant that rote learning was at the centre stage, which did not promote critical thinking skills among learners in schools [spatiality]. Supporting this narrative, Kayode-Olawoyin (2017) established that Civic Education in Nigeria was confronted with the problem of rote learning methods of teaching.

Additionally, the study by Alemnge and Andongaba (2021) established that Citizenship Education teachers in Cameroon mostly used teacher-centred methods in teaching which contradicted with the learner-centred methods as prescribed in the syllabus. Therefore, the use of not recommended teaching methods is detrimental in terms of effectively delivery and compromises the acquisition of expected Civic Education profile dimensions by learners. Further, the study by Boikhutso et al. (2013) discovered that Citizenship Education in Social Studies in Botswana was found to be taught using old methods of telling students instead of engaging them. In line with the establishment, other scholars such as Magasu et al. (2020a) also discovered that lecture method was the common method of teaching which teachers used in selected schools in Lusaka province during Civic Education lessons. Consistent with the above findings, Civic Education in Ethiopia was taught through 'plasma' where teaching was done through the television and learners followed the broadcast (Bayeh, 2016).

As observed by the researcher, teacher-centred mode of delivery makes learners to be passive followers because they just receive information from the teacher who is perceived to be a container full of knowledge. Figuratively, teachercentred mode of delivery can be likened to chicks in the nest, which always receive insects as food from their mother's mouth without choosing what to eat because of not getting involved in the hunting expedition.

Despite the current study revealing that teacher-centred teaching techniques were most prevalent mode of delivery in schools in Masaiti district [spatiality], it is important to state that other countries across the globe have embraced the $21^{\text {st }}$ century [temporality] teaching techniques, which stimulates the thinking capacity of learners during the learning process. According to the study that was conducted by USAID (2018) in Poland, students were exposed to open classroom environments. This meant that lessons were conducted using learner-centred teaching approaches. This revelation corresponds with the findings of Zuniga et al. (2020) in Chile and Zabun and Bektas (2019) in Turkey and France. Therefore, schools [spatiality] should be encouraged to use learner-centred teaching activities, which trigger student engagements thus, developing critical thinking skill in learners so that they are able to make wise decisions that are beneficial not only to themselves, their families and peers [relationality] but also to the society as a whole [spatiality]. In line with this position, Zuniga et al. (2020) posited that learner-centred teaching approaches were beneficial in the development of higher skills than over memorization.
However, during the current study, very few participants said that teachers of Civic Education taught the subject using different teaching methods. It is important to state that these participants said what they said because they just wanted to impress the researcher. Otherwise, traditional mode of delivered was common as noted by the researcher during lessons observations. Therefore, it was imperative for the researcher to capture even the views [corporeality] of the minority. This is because they had their own reasons for such position. One of the claimants was Lii who posited that:

\section{'...Actually, we do use various teaching methods. For example, we do have document study, group discussion, teacher exposition and we do advise ourselves to offer home works to the learners' (Lii.P5, 01.09.2021).}

Similarly, $N d u$ also claimed that she used of a variety of teaching methods depending on the prevailing situation. The verbatim below depict exactly what she said:

'This one I will talk about myself now. Depending of the lesson, I use different methods' (Ndu.p4, 31.08.2021).

Consistent with this establishment, the study by Bombardelli and Codato (2017) revealed that teaching methods to employ during the delivery of Civic Education in Italy were dependent upon schools and teachers. This was because they had the responsibility to decide on the choice of teaching methods. However, group work was not common because most teachers held the view that working in groups was not effective (Bombardelli \& Codato, 2017). Consequently, teachers should minimize over-reliance on didactic techniques which prevents learners from making sound and intelligent decisions (Odusanya \& Oni, 2019) but rather employ teaching techniques that appeal to learners (Nwaubani et al., 2016).

\section{CONCLUSION}

The study revealed that most of the teachers who were teaching Civic Education component in Social Studies lessons were not trained in Civic Education but trained in other study areas. Only a few teachers were found to be trained in Civic Education. However, most of them had degrees and a few with diplomas in their different specializations while others had primary school teacher's certificates. The reason why teachers with different specializations taught Civic Education component in Social Studies on secondment basis was due to shortage of qualified Civic Education teachers in schools. It was also revealed that most teachers who were teaching Civic Education component in schools had limited pedagogical knowledge. Traditional mode of delivery was the most prominent teaching method. Therefore, with all these revelations, one can conclude that the subject delivery was undoubtedly affected negatively. The status quo contributed to the poor academic performance of learners in Social Studies, which the district was experiencing at junior secondary school level. 


\section{RECOMMENDATIONS}

The study recommended the following:

- Teachers of Civic Education should employ $21^{\text {st }}$ century teaching approaches (learner-centred activities) during their delivery.

- The Ministry of Education should employ more qualified teachers of Civic Education.

- The Ministry of Education and the Curriculum Development Centre through the District Education Board Secretary officials and school authorities should enhance Continuous Professional Development programmes (CPDs) in schools.

\section{ACKNOWLEDGMENT}

Great thanks go to all the participants who took part in the study for their time and commitment.

\section{CONFLICT OF INTEREST}

Authors declare that they do not have any conflict of interest.

\section{REFERENCES}

Adeyemi, M. B., Boikhutso, K \& Moffat, P. (2003). Teaching and Learning of Citizenship Education at the Junior Secondary Level in Botswana. Pastoral Care in Education, 21(2), 35-40.

Akinyemi Olufunminiyi, A., \& Abiodun Adekunle, B. (2019). Assessment of Resources for Physics Teaching in Nigerian Senior Secondary Schools. International Journal of Humanities Social Sciences and Education, 6(8), 1-13. doi: http://dx.doi.org/10.20431/23490381.0608001

Alemnge, F. L. \& Andongaba, B. A. (2021). The Impact of Teaching Methods and Materials on the Teaching of Citizenship Education in Cameroon: A Study of Case Schools in Buea Municipality. Open Access Library Journal, 8, e6993. https://doi.org/10.4236/oalib.1106993

Bayeh, E. (2016). Role of civics and ethical education for the development of democratic governance in Ethiopia: Achievements and challenges. Pacific Science Review B: Humanities and Social Sciences, 1-6. http://dx.doi.org/10.1016/i.psrb.2016.09.012

Bickmore, K. (2014). Citizenship education in Canada: 'Democratic' engagement with differences, conflicts and equity issues? Citizenship Teaching \& Learning, 9(3), 257-278.

Boikhutso, K., Dinama, B. \& Kgotlaetsile, M. F. (2013). Secondary School Teacher's Perceptions of the Role of Social Studies in Fostering Citizenship Competencies. Journal of Education and Training Studies, 1(2),126-135.

Bombardelli, O., \& Codato, M. (2017). Country Report: Civic and Citizenship Education in Italy: Thousands of Fragmented Activities Looking for a Systematization. Journal of Social Science Education, $16(2), 73-85$

Cekse, I. (2021). Improving Civic and Citizenship Education in Latvia. https://doi.org/10.1007/978-3-030-71102-3_9

Cohen, A. (2013). Conceptions of Citizenship and Civic Education: Lessons from Three Israeli Civics Classrooms [Unpublished doctoral thesis]. Columbia University.

Guimond-Plourde, R. (2009). A Hermeneutic Phenomenological Approach to Understanding Stress- Coping as an Existential Phenomenon Lived by Healthy Adolescents. The Indo-Pacific Journal of Phenomenology(IPJP), 9(2), 1-13.

Kayode-Olawoyin, O. M. (2017). Civic Education in Secondary Schools: Its immediate Values and Life-Long impact. Nigerian Journal of Social Studies, 20(2), 82-91.

Kousar, R., \& Brett, P. (2020). Citizenship Education and Gender in Pakistan Teachers' and Students' Perspectives. The Social Educator, 38(2), 27-41.
Magasu, O., Muleya, G., \& Mweemba, L. (2020a). Teaching Strategies used in Civic Education Lessons in Secondary Schools in Zambia. International Journal of Research - Granthaalayah, 8(2), 39-46. Https://doi.org/10.5281/zenodo.3692546.

Magasu, O., Muleya, G., \& Mweemba, L. (2020b). Pedagogical Challenges in Teaching Civic Education in Secondary Schools in Zambia. International Journal of Science and Research (IJSR), 9(3), 1483 1488.

Mainde, D., Chola, D. K., \& Mpolomoka, D. L. (2021). Interrogating Civic Education Pedagogies that Stimulate Political Participation in Selected Secondary Schools in Zambia. International Journal of Research and Innovation in Social Science (IJRISS), 5(2),269-279.

Ministry of Education. (1996). Educating Our Future. Lusaka: Government Printers.

Ministry of Education. (2013). The Zambia Education Curriculum Framework. Lusaka: Curriculum Development Centre.

Ministry of Education, Science, Vocational Training and Early Education. (2013). Social Studies Syllabus Grades 8-9. Lusaka: Curriculum Development Centre.

Ministry of Education, Science, Vocational Training and Early Education. (2013). Civic Education Syllabus Grades 10-12. Lusaka: Curriculum Development Centre.

Ministry of General Education, (2019). Standards of Practice for the Teaching Profession in Zambia. Lusaka: MoGE.

Ministry of National Development and Planning, (2017). Seventh National Development Plan 2017-2021. Lusaka: GRZ.

Mohit, B. (2018). Case Study of Civics Education. Journal of Research \& Methods in Education, 8(5), 22-31.

Mufalo, S. M. \& Kabeta, M. R. (2019). Challenges of School Re-Entry among Learner-Mothers and Mitigation Strategies Instituted by Stakeholders in Schools in Masaiti District. International Journal of Humanities Social Sciences and Education (IJHSSE), 6(9), 73-82. doi: http://dx. doi.org/10.20431/2349-0381.060908.

Mufalo, S. M. (2021). Exploring Civic Education As A Catalyst To Learner Transformation In Zambian Schools: A Glance On The Developed Civic Education Pedagogical Content Knowledge (CEPCK) Model. International Journal of Research and Scientific Innovation (IJRSI), 8(7), 89-95. doi: https://dx. doi.org/10.51244/IJRSI.2021.8711

Mufalo, S. M., Mulubale, S., Muleya, G., \& Simui, F. (2021). Challenges faced by Combined Schools in Masaiti district which hinders the provision of Quality Education. International Journal of Research and Innovation in Social Science (IJRISS), 5(3), 146-154

Muleya, G. (2018a). Civic education versus citizenship education: Where is the point of convergence? Journal of Lexicography and Terminology, $1(2), 125-148$.

Muleya, G. (2019). Curriculum Policy and Practice of Civic Education in Zambia: A Reflective Perspective. In Peterson, A., Stahl, G., Soong, H. (Eds.) The Palgrave Handbook of Citizenship and Education. Cham, Switzerland: Palgrave Macmillan.

Muntengwa,W., Namadula, B., Hamainza, V., Simwatachela, R., Kakana, F., Simui, F. and Muleya, G. (2020). Unearthing Disablers in the Cultivation of Civic Skills among Learners in Selected Secondary Schools in Lusaka District, Zambia. International Journal of Research and Innovation in Social Science (IJRISS), IV (IX), 228238 .

Nwaubani, O. O., Otoh-Offong, A. N., Usulor, V. I. \& Okeke, J. N. (2016). Resource Availability and Utilization Dimension in the Implementation of Junior Secondary Social Studies Curriculum in Ebonyi State, Nigeria. Australian Journal of Basic and Applied Sciences, 10(14), 1-9.

Odusanya, S. P., \& Oni, A. (2019). Civic Education and Pupils' Civic Dispositions in Ghana and Nigeria: A Comparative Analysis. Journal of Education and Research, (9)1, 13-27.

Shava, G. N. \& Nkengbeza, D. (2020). Qualitative Research Paradigm: A Design for Distance Education Researchers. Namibia CDP Journal for Educators, 237-258.

Simui, F. (2018). Lived Experiences of Students with Visual Impairments at Sim University in Zambia: A Hermeneutic Phenomenological Approach [Unpublished doctoral dissertation]. University of Zambia. http://dspace.unza.zm/handle/123456789/5884 


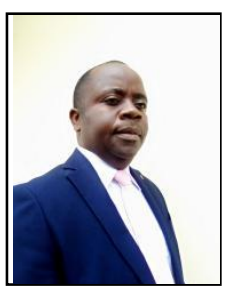

S. M. Mufalo is a Head of Department Social Sciences at Mishikishi Secondary School and has 17 years of teaching experience. He holds a Certificate in primary teaching, Diploma in secondary teaching, Bachelor of Arts with Education (Civic Education \& Religious Studies), Master of Arts in Civic Education \& Transformational Leadership and currently pursuing Doctor of Philosophy $(\mathrm{PhD})$ in Civic Education at the University of Zambia.

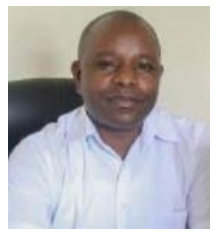

Prof. Gistered Muleya is an educationist with vast experience in Civic/Citizenship Education, Educational Studies, Human Rights Education, Democracy and Governance and Global Studies. He has over 24 years of teaching experience both at the secondary school and university level. $\mathrm{He}$ has presented papers both locally and internationally and has also published in local and international peer-reviewed journals. Currently, he is a Lecturer/Researcher of Civic/Citizenship Education in the School of Education at the University of Zambia. He also serves as an Assistant Director in charge of Postgraduate programmes at the Institute of Distance Education of the University of Zambia.

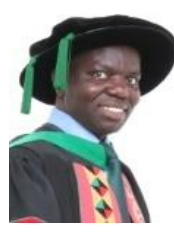

Dr. Francis Simui serves as a Senior Lecturer with keen interest in the welfare of the vulnerable persons who has served the University of Zambia in various capacities. Has vast experience in ODL Quality Assurance, having been part of the core team, which developed the SADC ODL M \& E Framework, Zambian ODL Framework and University of Zambia ODL Policy. Francis is a member of the Advisory Board of the Network of Open Educational Resources \& Multimodal Self-Directed Learning in Southern Africa through North-West University, South Africa. 